\title{
Importance in prenatal diagnosis of the detection of isolated aberrant right subclavian artery
}

\author{
Özge Kızılkale, Canan Yılmaz Torun, Mert Yeşiladalı, Pınar Cenksoy, Gazi Yıldırım, Oluş Api \\ Department of Gynecology \& Obstetrics, Faculty of Medicine, Yeditepe University, Istanbul, Turkey
}

\begin{abstract}
Objective: We aimed to evaluate the significance of isolated aberrant right subclavian artery (ARSA) diagnosis.

Case: In this case study, we are presenting the prenatal diagnosis and fetal results of two cases (forty-year-old at 20 weeks of gestation and twenty-eight-year-old at 23 weeks of gestation) who were diagnosed with ARSA.

Conclusion: As aberrant right subclavian artery (ARSA), which has the incidence rate of $1.4 \%$ in normal population, has increased up to $40 \%$ in cases with Down syndrome, it has been considered to add ARSA into the markers of Down syndrome which can be established with prenatal ultrasonography diagnosis as one of the vascular markers.
\end{abstract}

Key words: Aberrant right subclavian artery, prenatal diagnosis.

\section{Introduction}

Normally, right subclavian artery originates from brachiocephalic artery which is the first branch of aorta at aortic arch level. Aberrant subclavian artery (ARSA), the one of the aortic arch anomalies, is seen in 1-2\% of general population and in this case, right subclavian artery originates from aortic arch as the 4th branch. "Vascular signs" have also been added recently into the anomalies seen in Down syndrome frequently and used as ultrasonographic marker in the antenatal risk evaluation. ${ }^{[2]}$ ARSA, which has been reported as $40 \%$ in cases with Down syndrome, has been suggested to be a marker for Down syndrome in the literature as a vascular sign and become one of the findings in prenatal ultrasonographic diagnosis. ${ }^{[1,3,4]}$
İzole aberan sağ subklavian arterin saptanmasının prenatal tanıdaki önemi

Amaç: İzole aberan subklavian arter (ARSA) tanısının önemini değerlendirmeyi amaçladık.

Olgu: Biz bu olgu sunumunda, kırk yaşında 20. gebelik haftasında ve yirmi sekiz yaşında 23. gebelik haftasında izole ARSA tanısı alan iki olgunun prenatal tanısı ve fetal sonucunu sunuyoruz.

Sonuç: Normal popülasyonda görülme insidansı \% 1.4 olan aberan sağ subklavian arterin (ARSA) Down sendromlu olgularda insidansının \%40'a kadar çıkması, ARSA'nın vasküler işaretlerden biri olarak prenatal ultrasonografik tanısı konulabilen Down sendromu belirteçleri arasına girmesini gündeme getirmiştir.

Anahtar sözcükler: Aberan sağ subklavian arter, prenatal tanı.

In this article, we aimed to present two cases established with isolated ARSA diagnosis in the detailed routine obstetric ultrasonography made between 18 and 22 weeks of gestation, to compile related up-to-date literature and to make contribution to the literature for the significance of ARSA on Down syndrome as an ultrasonographic marker.

\section{Case Report}

Case 1

Forty-year-old pregnant woman (Gravida 1, Parity 0) referred to our perinatology clinic for detailed routine obstetric ultrasonography at 20 weeks of gestation. In
Correspondence: Özge Kızlkale, MD. Yeditepe Üniversitesi Tıp Fakültesi Kadın Hastalıkları ve Doğum Kliniği, İstanbul, Turkey.

e-mail: drkizilkale@gmail.com

Received: August 16, 2013; Accepted: November 5, 2013
Available online at: www.perinataljournal.com/20140221011 doi:10.2399/prn.14.0221011 QR (Quick Response) Code: 
the detailed obstetric ultrasonography performed, aberrant subclavian artery was observed as heading rightwards behind the trachea on three vessel crosssection. No additional major and/or minor anomaly was detected except ARSA in the ultrasonographic examination. The family was informed about isolated ARSA presence and genetic consultancy was provided about Down syndrome risk due to advanced maternal age, and amniocentesis was done for karyotype analysis. When the result of amniocentesis was found as 46,XX normal constitutional karyotype, the pregnant woman delivered a healthy $3400 \mathrm{~g}$ baby with 9/10 Apgar score on 39 weeks of gestation. No symptom associated with ARSA was observed in the baby. The presence of ARSA was confirmed in the baby by postpartum echocardiography done by pediatric cardiology clinic, and the baby has been still followed-up regularly by the pediatric cardiology clinic (Fig. 1).

\section{Case 2}

The aberrant subclavian artery was observed as heading rightwards behind the trachea on three vessel cross-section in the detailed routine obstetric ultrasonography of 28-year-old pregnant woman (Gravida 1, Parity 0 ) at 23 weeks of gestation. The family was provided genetic consultancy about the non-existence of risk increase at double test previously made, having young maternal age and detecting no additional anomaly in the ultrasonography in terms of the markers which make to consider Down syndrome, and the family did not want amniocentesis for karyotype analysis. The patient delivered a healthy $3400 \mathrm{~g}$ baby with $9 / 10$ Apgar score at 38 weeks of gestation. After the birth, no symptom associated with ARSA was observed in the baby. The presence of ARSA was confirmed in the baby by postpartum echocardiography done by pediatric cardiology clinic, and the baby has been still followed-up regularly by the pediatric cardiology clinic.

\section{Discussion}

While congenital anomalies of aortic arch are seen commonly, ARSA with the incidence rate of $1-2 \%$ among general population is the most common one among these anomalies and it is generally located on the right. ${ }^{[5]}$

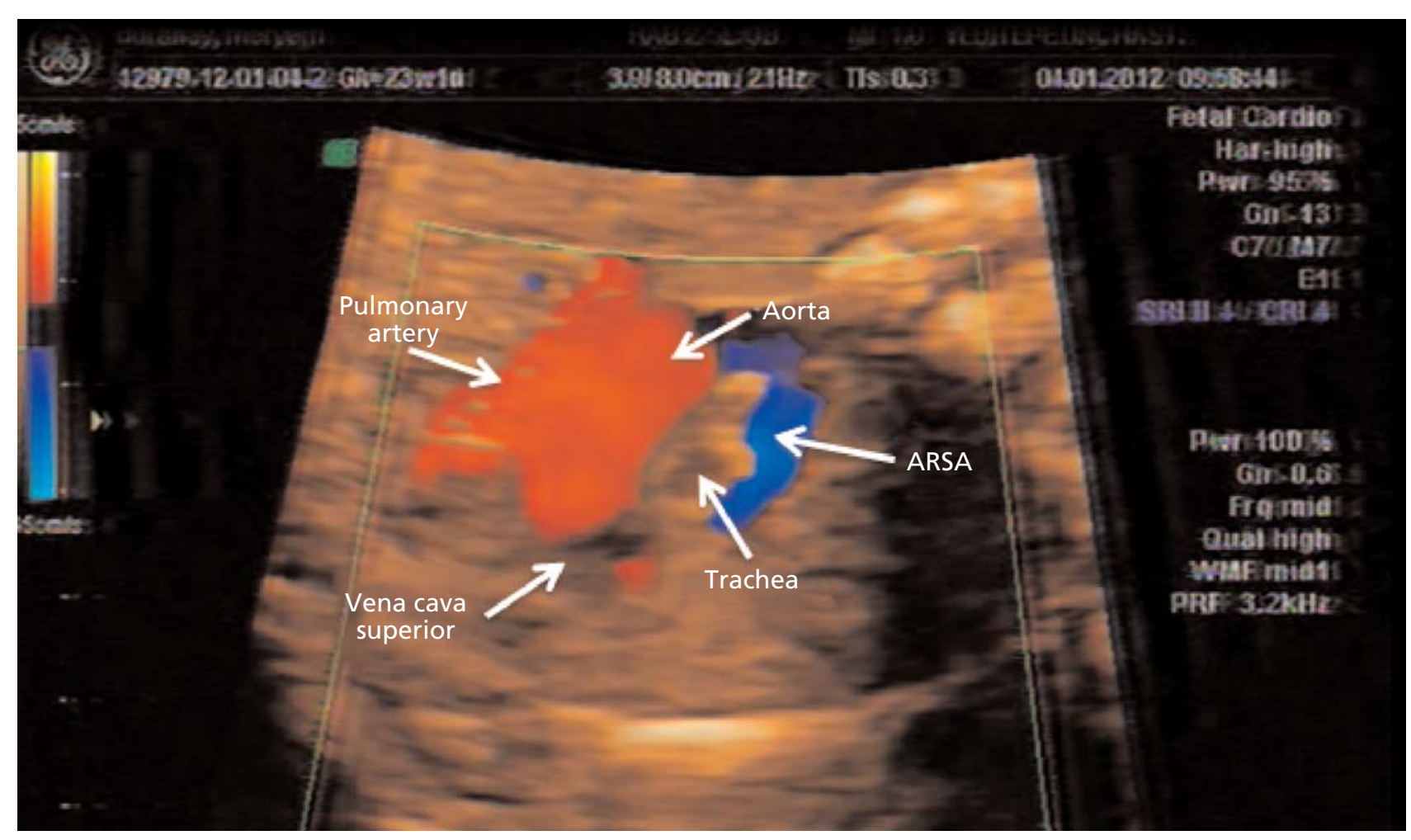

Fig. 1. The view of aberrant right subclavian artery in fetal echocardiography. 
It is generally found when examining mediastinal diseases or during autopsy. Abnormal development or absence of right fourth aortic arch together with the presence of 7 th intersegmental artery at embryonal period causes the formation of aberrant right subclavian artery. In cases with aberrant right subclavian artery, it passes behind the esophagus in $80 \%$ of the cases, between esophagus and trachea in $15 \%$ of the cases, and in front of trachea or main bronchus in $5 \%$ of the cases. Although it is asymptomatic in many cases, it may cause symptoms such as dysphagia, recurrent aspirations, dyspnea or coughing in case of pressure on esophagus, trachea or laryngeal nerve. ${ }^{[6]}$

There are many studies in the literature which report that specific cardiac anomalies such as isolated ventricular septal defect, isolated and/or multiple intracardiac echogenic focus, pericardial effusion and tricuspid regurgitation are associated with Down syndrome..$^{[7-9]}$ Although there are studies associating aberrant right subclavian artery originated from left aortic arch with Down syndrome, there has been still no specific finding showing that ARSA is associated with Down syndrome. ${ }^{[2]}$

According to postnatal radiographic studies, ARSA incident increases up to $16-35 \%$ in infants or adults with Down syndrome. It was found in the study of Chaoui et al. that the incidence rate of ARSA was 35\% in cases with Down syndrome while it was $1.4 \%$ in cases without Down syndrome. ${ }^{[10,11]}$ While ARSA incidence is approximately $1.5 \%$ in general population, it may increase up to $28.6 \%$ in cases with Down syndrome, and up to $18.2 \%$ in fetuses with Trisomy $18 .{ }^{[8]}$

\section{Conclusion}

The cases that we presented are the ones which were found to have isolated ARA which were not concomitant chromosomal or structural anomaly. Therefore, due to the possibility of ARSA being with other concomitant anomalies, carrying out detailed ultrasonographic examination and fetal echocardiography before defining as isolated in the management would be an appropriate approach. Also, it should be carefully examined in the ultrasonography whether there is any additional concomitant anomaly for the fetuses diagnosed with ARSA or not, and consultancy should be provided to families accordingly. However, in order to consider isolated ARSA presence among the minor anomalies used as ultrasonographic marker for antenatal risk evaluation during Down syndrome screening, we believe that broader prospective studies evaluating and supporting this idea are required.

Conflicts of Interest: No conflicts declared.

\section{References}

1. Zapata H, Edwards JE, Titus JL. Aberrant right subclavian artery with left aortic arch: associated cardiac anomalies. Pediatr Cardiol 1993;14:159-61.

2. Zalel Y, Achiron R, Yagel S, Kivilevitch Z. Fetal aberrant right subclavian artery in normal and Down syndrome fetuses. Ultrasound Obstet Gynecol 2008;31:25-9.

3. Goldstein W. Aberrant right subclavian artery in mongolism. Am J Roentgenol Rad Ther Nucl Med 1965;95:131-4.

4. Rathore MH, Sreenivasan VV. Vertebral and right subclavian artery abnormalities in the Down syndrome. Am J Cardiol 1989;63:1528-9.

5. Borenstein M, Minekawa R, Zidere V, Nicolaides KH, Allan LD. Aberrant right subclavian artery at 16 to $23+6$ weeks of gestation: a marker for chromosomal abnormality. Ultrasound Obstet Gynecol 2010;36:548-52.

6. Abraham V, Mathew A, Cherian V, Chandran S, Mathew G. Aberrant subclavian artery: anatomical curiosity or clinical entity. Int J Surg 2009;7:106-9.

7. Devore GR. The role of fetal echocardiography in genetic sonography. Semin Perinatol 2003;27:160-72.

8. Bromley B, Lieberman E, Laboda L, Benacerraf BR. Echogenic intracardiac focus: a sonographic sign for fetal Down syndrome. Obstet Gynecol 1995;86:998-1001.

9. Sharland G, Lockhart S. Isolated pericardial effusion: an indication for fetal karyotyping? Ultrasound Obstet Gynecol 1995;6:29-32.

10. Chaoui R, Thiel G, Heling KD. Prevalence of an aberrant right subclavian artery (ARSA) in normal fetuses: a new soft marker for trisomy 21 risk assessment. Ultrasound Obstet Gynecol 2005;2:356.

11. Yıldırım G, Attar R, Çetinkaya N, Fıçıcıoğlu C, Yeşiladalı N. Prenatal tanısı konulan bir izole aberran să̆ subklavian arter (ARSA) vakası ve literatürün tartısılması. Zeynep Kamil Tıp Bülteni 2009;40:135-7. 